АНАЛІЗ СУЧАСНИХ ПІДХОДІВ ДО ВИВЧЕННЯ ПОЛІТИЧНОЇ ІДЕНТИЧНОСТІ В ЗАРУБІЖНІЙ СОЦІОЛОГІї

\title{
ANALYSIS OF MODERN SOCIOLOGY APPROACHES TO THE STUDY OF POLITICAL IDENTITY IN FOREING
}

Стаття присвячена аналізу сучасних підходів до вивчення політичної ідентичності в зарубіжній сочіології. Відзначається прагнення дослідників розширити простір аналізу даного френомену. Показано, що з позицій соціально-економічного підходу політична ідентичність розглядається дослідниками як продукт економічних та соціальних структур, які мають визначальний вплив на особу та програмують ї політичну поведінку. у межах когнітивного підходу політична ідентичність визначається науковцями як генералізована настанова, дія якої підтримується когнітивними процесами на нейропсихологічному рівні. Прихильниками персонологічного підходу політична ідентичність розглядається як центральне каузальне утворення Я-концепції особистості. Для представників наративного підходу політична ідентичність є різновидом соціальноі ідентичності, що пов'язана з історичною пам'яттю й актуалізується через занурення в емоційно забарвлений життєвий простір. З позичій аксіологічного підходу політична ідентичність розглядається дослідниками як складова частина морального світогляду людини, в основу якого закладено певну систему цінностей. Під час проведення аналізу специфріки формування ідентичності у процесі соціалізації дослідники розглядають політичну ідентичність як похідну від базових культурних настанов. Імплементація досвіду зарубіжних дослідників в українські реаліі дозволить розширити перелік маркерів політичної ідентичності й оновити підходи до їі вивчення завдяки застосуванню якісно нових інструментів. Перспективи вивчення політичної ідентичності полягають у проведені міждисциплінарних досліджень з урахуванням проаналізованих підходів.

Ключові слова: політична ідентичність, сочіально-економічний підхід, когнітивний підхід, персонологічний підхід, наративний підхід, аксіологічний підхід, соціалізація.

This article is devoted to analysis of modern approaches to studying political identity in foreign sociology. The researchers' commitment to widening the space of analysis of this phenomena is noted. It is shown, that from social-economical approach's point of view political identity is seen by the researchers as a product of economic and social structures which have a decisive impact on a personality, and program their political behavior. In extents of cognitive approach political identity is defined by the scientists as a generalized attitude, which is supported by cognitive processes on neuropsychological level. Supporters of personological approach view political identity as a central causal entity of selfconcept of a personality. For representatives of the narrative approach political identity is a kind of social identity, which is connected to historical memory, and is actualized through experiencing emotionally charged space of living. From positions of axiological approach political identity is viewed by the researchers as a component part of moral worldview of a human being, with some value system lying in its foundation. By analyzing the specifics of identity formation in context of process of socialization, the researchers define political identity as derivative from basic cultural attitudes. Implementation of experience of foreign researchers in Ukrainian realities would allow to widen the list of markers of political identity and to renew approaches to studying it by using qualitatively new instruments. Prospects of future studies of political identity are for conduction of cross-disciplinary researches with analyzed approaches taken into account. Key words: political identity, social-economical approach, cognitive approach, personological approach, narrative approach, axiological approach, socialization.
Політична ідентичність громадян України протягом останніх тридцяти років формується в умовах суспільного транзиту. Суперечливий характер процесів соціальних перетворень у країні впливає на амбівалентність змісту й асинхронність динаміки змін політичної ідентичності українців. У зв'язку із цим виникає потреба в більш детальному вивченні специфіки політичної ідентичності громадян України.

У соціологічній науці накопичений чималий досвід досліджень проблем політичної ідентичності, початок вивчення яких було покладено в середині XX ст. в межах мічиганського проєкту, представниками якого політична ідентичність розглядалась як партійна [11; 12]. Відтоді пройшло три «хвилі» концептуалізації поняття «політична ідентичність» [5], розроблено низку цікавих теоретичних концепцій (Д. Батлер та Д. Стоукс, Дж. Уелш, Р. Картер, Дж. Хелмс, Ф. Шлезінгер, М. Кастельс,
Т. Райсс, М. Емерсон, В. Лот, І. Нойманн, Б. Страт, Ф. Черутті) [3; 7; 10; 13; 14; 15; 20; $22 ; 24 ; 27]$, запропоновано електорально поведінкові (М. Шенкс, У. Міллер), комунікаційні (Т. Дж. Колтон) та самоідентифікаційні (Р. Барт, Р. Хакфельд, Е. Даунс, Дж. Спрагі) моделі політичної ідентичності [2; 9; 17; 23].

Однак, як зазначають вітчизняні соціологи (О. Вишняк, А. Ручка, Ю. Шведа), згадані концепції та моделі не повною мірою враховують специфіку нашого суспільства і не можуть бути використані в чистому вигляді для аналізу політичної ідентичності українців $[1 ; 4 ; 6]$. Деяка незадоволеність наявними напрацюваннями спостерігається і в зарубіжній соціології, де науковцями продовжується активний пошук нових підходів до вивчення політичної ідентичності.

Мета статті полягає в розкритті особливостей сучасних підходів до вивчення політичної ідентичності в зарубіжній соціології. 
Політична ідентичність залишається у фокусі уваги дослідників, які прагнуть розширити простір традиційних вимірів аналізу даного феномену. Так, Н. Крістенсен у статті «Значення та виміри політичної ідентичності» розглядає низку інших підходів до концептуалізації поняття «політична ідентичність» [19]. Починаючи з марксистського та диспозиційно-структурального підходу П. Бурдьє, він зазначає, що ці підходи $є$ досить обмеженими, оскільки розглядають будь-яку ідентичність, зокрема й політичну, як продукт економічної чи соціальної структур. Такий підхід передбачає, що індивід, залежно від своєї позиції в системі виробництва або в соціальній структурі, «запрограмований» обирати ту чи іншу ідентичність, не має можливостей для здійснення самостійного вибору. Проте соціальна практика засвідчувала, що сфера політики як така, процеси індивідуальної ідентифікації мають деяку автономію, наявна низка чинників (як-от політична культура, ціннісні орієнтації), що не вкладаються в ці концепції [19; 26].

Досить цікавим $є$ когнітивний підхід до вивчення політичної ідентичності. Серед праць представників цього підходу можна виокремити дослідження Дж. ван Бавель і А. Перейри (J. Van Bavel, A. Pereira) особливостей політичних переконань, що ґрунтуються на ідентичності [25, с. 213-224]. Автори намагаються поєднати традиційні погляди на політичну ідентичність (яка притаманна прихильникам окремих політичних партій) та новітні досягнення у сфері нейропсихології, апеляція до яких є трендом останнього десятиріччя у сфері гуманітарного знання. Дослідниками описано, яким чином та чому ідентифікація з політичними партіями - так звана партійність - може вплинути на оброблення інформації мозком. На їхню думку, партійна ідентичність виступає як генералізована настанова, що може змінювати спогади, імпліцитну оцінку та навіть перцепцію: «Люди віддають неявну перевагу щодо запропонованої політики членам своєї політичної групи (демократ чи республіканець) незалежно від змісту політики, вона відповідає їхній ідеології» [25, с. 218].

Автори наводять приклади досліджень, у яких було вивчено взаємозв'язок між математичними навичками та вирішенням політичних проблем. Так, у контрольному стані люди, які були сильними в математиці, змогли ефективно вирішити аналітичне завдання. Однак коли політичний контекст був доданий до тієї ж аналітичної проблеми - порівняння даних про злочинність у містах, у яких заборонена зброя, і в містах, де вона не заборонена, математичні навички вже не гарантували правильного вирішення проблеми. Також авторами було доведено, що партійна ідентичність впливає на пам'ять. Ними встановлено, що люди схильні більше запам'ятовувати ту інформацію, яка підтримує їхню партійну ідентичність.

Дж. ван Бавель і А. Перейра наводять приклади впливу партійної приналежності на візуальне сприймання (а саме на сприймання людей після перегляду відео про політичний протест залежно від того, які ідеї приписувались його учасникам) [25, с. 213-224].

Дослідники пропонують власні засоби зниження впливу партійної ідентичності на обробку інформації. Водночас вони визнають, що зміна помилкових переконань щодо політичного кандидата може не змінити оцінок, оскільки вони підтримуються різними когнітивними процесами. Наприклад, виправлення помилкових позитивних переконань щодо Дональда Трампа було достить, щоб зруйнувати ці переконання. Однак це не змінило підтримки Дональда Трампа серед його прихильників. Автори роблять висновок, що доступ до інформації не гарантує свободи від ідеологічних настанов, і політична поведінка багато в чому залишається ірраціональною; «Таким чином, це сучасний парадокс, як наш розширений доступ до інформації ізолював нас в ідеологічних бульбашках та заважає нам бачити факти» [25, с. 222].

Варто відзначити, що прихильників певних політичних партій автори позначають терміном «партизан» (partisan), який в останні роки в науковій літературі широко вживається саме в такому сенсі.

З позицій персонологічного підходу С. Чен і О. Урмінський досліджували роль причинних (каузальних) переконань у політичній ідентичності та голосуванні [16, с. 27-38].

Автори доводять, що люди, які вважають, що їхня політична ідентичність справді пов'язана з іншими ознаками їхньої Я-концепції, будуть більш імовірно діяти відповідно до норм цієї ідентичності, ніж ті, хто вважають, що їхня політична ідентичність $€$ відносно периферійною (тобто має відносно менше причинно-наслідкових зв'язків): «Якщо причинно-наслідкові основні ознаки сприймаються як більш визначальні для Я-концепції, тоді зміни цих особливостей змусять людей бути більш чутливими до руйнування цілісності їхньої ідентичності» [16, с. 28].

С. Чен і О. Урмінський уводять поняття центрального чинника, який обчислюється шляхом підсумовування числа інших особливостей, з якими вони причинно пов'язані як причина або наслідок (своєрідне центральне каузальне утворення Я-концепції): «Чим більше центральний чинник визначає Я-концепцію, тим політична ідентичність сильніше пов'язана з поведінкою в людей, для яких політична ідентичність $є$ більш причинно-наслідковою порівняно з людьми, для яких політична 
ідентичність є більш причинно-периферійною» [16, с. 28].

Зазначимо, що цей показник схожий на «ступінь центральності» в аналізі соціальної мережі Л. Фрімен (L. Freeman), оскільки тут теж враховується число прямих зв'язків, які має вузол.

Однак, на відміну від аналізу соціальних мереж, тут «вузли» представляють різні аспекти Я-концепції (наприклад, політична партія, стать тощо). Крім того, зв'язки не просто асоціативні, але такі, що одна особливість впливає або формує іншу.

3 позицій аксіологічного підходу американські дослідники К.П. Вінтеріч, Й. Дженг та В. Мітал (K.P. Winterich, Y. Zhang, V. Mittal) вивчали вплив політичної ідентичності (під якою в американських реаліях маються на увазі «лібералізм» та «консерватизм») на пожертви на благодійність [28, с. 346-354]. Авторами було зроблено припущення, що існує кореляція між характером благодійних ініціатив (приватний чи державний) та політичною ідентичністю благодійника. Це припущення було підтверджено у процесі досліджень, коли респонденти надали більшу підтримку тим благодійним проєктам, чиї засади відповідали їхнім власним переконанням. Зокрема, респонденти, що ідентифікували себе прихильниками республіканської партії, надавали більшу підтримку тим благодійним проєктам, що керувалися приватно, і навпаки, демократи віддавали перевагу тим ініціативам, що виходили від державних інституцій.

Також авторами була встановлена кореляція між характером цінностей, що лежать в основі того чи іншого благодійного проєкту, та моральним світоглядом опитаних. Зокрема, консервативні респонденти віддавали перевагу тим благодійним програмам, що спрямовані на підтримання порядку, традицій, «моральної чистоти» чи були принаймні позиційовані таким чином. Ліберали, натомість, були більше схильні жертвувати на ті проєкти, що були спрямовані на підтримку вразливих членів суспільства, підтримку соціальної справедливості загалом. Науковці наголошують на тому, що дана кореляція є слушною для тих респондентів, що мають високий рівень інтерналізації морального світогляду. Для інших опитаних даний зв'язок не є значущим. Авторами був зроблений висновок, що правильне позиціонування благодійного проєкту залежно від характеру політичної ідентичності та пов'язаного з нею морального світогляду потенційних благодійників може збільшити обсяги пожертв [28, с. 350].

Нестандартне, але вельми цікаве (як за змістом, так і за процедурою) дослідження було проведено Л. Брауном та К.А. Ібарра (L. Brown \& K.A. Ibarra), які застосували нара- тивний підхід до вивчення ролі туризму в мобілізації політичної ідентичності [8, с. 79-88].

Автори провели якісне дослідження, опитуючи у формі інтерв'ю осіб, що здійснювали мандрівки до Іспанії за місцями, пов'язаними із громадянською війною. Відібрані методом «снігової кулі» респонденти (з Великобританії, Норвегії та США) мали вищу освіту, чітко окреслену політичну ідентичність (лівосоціалістичного спрямування), отже, їхні поїздки були мотивовані бажанням виразити власну політичну ідентичність, а також прагненням вшанувати загиблих у війні й одразу після неї республіканців.

Дослідниками було встановлено, що фізична присутність у місцях битв часів громадянської війни та місцях масових поховань викликала в опитаних сильні емоції як позитивного, так і негативного характеру. 3 одного боку, відвідання пам'ятних місць посилювало ідентифікацію з лівим спектром політичних ідей, викликало почуття гордості за мужність як самих іспанців, так і бійців-інтернаціоналістів (зокрема, із їхніх країн), що боролися проти військ Франсіско Франко. 3 іншого - викликали почуття горя з огляду на усвідомлення поразки республіканців, відсутність підтримки їхньої справи тодішніми урядами їхніх країн. Респонденти також зазначали засмученість та навіть обурення через те, що сучасний іспанський уряд приділяє мало уваги подіям тих років [8, с. 79-88].

Л. Браун та К.А. Ібарра стверджують, що політична ідентичність є водночас причиною здійснення туристичної поїздки та її наслідком. Мотивація відвідати пам'ятні місця в Іспанії виникала в респондентів через їхню зацікавленість і обізнаність в історії соціалістичного руху, у якій Іспанська Республіка відіграє важливу роль. А самі відвідини підтримували їхні політичні переконання, надаючи їм більш емоційного забарвлення. Саму політичну ідентичність автори розглядають як різновид соціальної ідентичності, що передбачає передусім приналежність до певної політичної групи. Проте автори підкреслюють розмитість межі між особистою та соціальною ідентичністю, підкреслюють їхню взаємопов'язаність та взаємозалежність. У межах застосованого наративного підходу автори підкреслюють, що політична ідентичність надає «форми» баченню тих чи інших історичних подій, стає однією із призм, крізь яку інтерпретуються ті чи інші події, як у минулому, так і в сьогоденні [8, с. 84].

Вивчення особливостей формування політичної ідентичності у процесі соціалізації було здійснено групою європейських дослідників. Р. Реккер, Л. Кейсерс, С. Брені та В. Міус (R. Rekker, L. Keijsers, S. Branje, W. Meeus), яка провела когортно-послідовне лонгітюдне 
дослідження нідерландської молоді, спрямоване як на вивчення динаміки розвитку політичної ідентичності респондентів, так і на виявлення того, чи базові настанови формують ідентичність, чи навпаки, ці настанови формуються на базі тієї чи іншої політичної ідентичності [21, с. 1-33]. У результаті проведених досліджень було виявлено, що ідентичність молоді частіше формувалась в узгодженості з базовими настановами, аніж навпаки. Дослідниками було також зафіксовано, що високоосвічені опитані частіше коригували свої настанови зі своєю ідентичністю. Також авторами було встановлено, що ранні культурні настанови утворюють таку ідентичність, що може згодом визначати політичні настанови. Політична ідентичність в даному дослідженні розглядається як ідентифікація респондентом себе з лівою чи правою політичною течіями. Даний поділ є релевантним для реалій Нідерландів, оскільки партії у країні мають чітку ідеологічну спрямованість, більшість населення розуміється на особливостях лівої та правої ідеологій, досить рано визначається із приналежністю до однієї з них. Як бачимо, у зарубіжній науці спроби всебічного та ретельного вивчення феномену політичної ідентичності тривають. Аналогічні процеси відбуваються у вітчизняній науці і будуть нами проаналізовані додатково в майбутніх публікаціях.

Аналіз сучасних підходів до вивчення політичної ідентичності в зарубіжній соціології свідчить про прагнення дослідників розширити простір аналізу даного феномену, який розглядається ними: 1) як продукт економічних та соціальних структур (соціально-економічний підхід); 2) як генералізована настанова, дія якої підтримується когнітивними процесами (когнітивний підхід); 3) як центральне каузальне утворення Я-концепції особистості (персонологічний підхід); 4) як складова частина морального світогляду людини (аксіологічний підхід); 5) як наратив, що пов'язаний з історичною пам'яттю й актуалізується через занурення в емоційно забарвлений простір (наративний підхід); 6) як похідна від базових культурних настанов (підхід до вивчення особливостей формування політичної ідентичності у процесі соціалізації).

На наш погляд, імплементація досвіду зарубіжних дослідників в українські реалії дозволить розширити перелік маркерів політичної ідентичності й оновити підходи до її вивчення завдяки застосуванню якісно нових інструментів. 3 огляду на встановлені тенденції, перспективи вивчення політичної ідентичності полягають у проведені міждисциплінарних досліджень з урахуванням проаналізованих підходів.

\section{ЛITЕРАТУРА:}

1. Вишняк О. Електоральна соціологія: історія, теорії, методи. Київ : Ін-т соціології НАНУ, 2000. 308 с.

2. Миллер У. Политическое поведение: вчера и сегодня / под ред. Р. Гудина, Х.-Д. Клингеманна. Политическая наука: новые направления. Москва, 1999. С. 300.

3. Нойманн И. Использование «Другого»: образы Востока в фрормировании европейских идентичностей. Москва : Новое издательство, 2004. 336 c.

4. Ручка А. Політико-ідеологічна самоідентифікація населення сучасної України. Українське суспільство 1992-2012. Стан та динаміка змін. Соціологічний моніторинг. Київ : Ін-т соціології НАН України, 2012. С. 29-40.

5. Соснюк Є. Концепції політичної ідентичності в соціальних науках. Соціологія: теорія, методи, маркетинг. 2019. № 4. C. 118-135. DOI: 10.15407/ sociology2019.04.118.

6. Шведа Ю. Трансорормації партійної системи в контексті транссормації політичної системи в Україні. Українська національна ідея: реалії та перспективи розвитку : збірник наукових праць. Львів : Видавництво Національного університету «Львівська політехніка», 2007. № 19. С. 165-172.

7. Эмерсон М. Экзистенциональная дилемма Европы. Вестник Европы. 2005. № 15. С. 41-65.

8. Brown L., Ibarra K.A. Commemoration and the expression of political identity. Tourism Management. 2018. № 68. P. 79-88.

9. Burt R. Structural Holes: The Social Structure of Competition. MA : Cambridge, 1992. 313 p.

10. Butler D., Stokes D. Political Change in Britain. London, 1974. 516 p.

11. Elections and the political order / A. Campbell et al. New York : Wiley, 1966. 385 p.

12. The American Voter / A. Campbell et al. New York: Wiley, 1960. 573 p.

13. Carter R.T., Helms J.E. White Racial Identity Attitudes and Cultural Values. Black and White racial identity: Theory, Research and Practice. Journal of Multicultural Counseling and Development. 2003. Vol. 31. № 4. P. 226-244.

14. Castels M. The Power of Identity. Oxford : Blackwell, 1997. $280 \mathrm{p}$.

15. Cerutti F. Towards the political identity of the Europeans: An Introduction. A soul for Europe. On the political and cultural identity of the Europeans. 2001. Vol. 1. P. 26-45.

16. Chen S.Y., Urminsky O. The role of causal beliefs in political identity and voting. Cognition. 2019. № 188. P. 27-38. DOI: 10.1016/j.cognition. 2019.01.003.

17. Colton T.J. Transitional Citizens: Voters and What Influences Them in the New Russia. London : Cambridge, 2000. 336 p.

18. Freeman L.C. Centrality in social networks conceptual clarification. Social Networks. 1978. № 1. P. 215-239.

19. Kristensen N.N. The Meanings and Dimensions of Citizens' Political Identity: Approaching an Under- 
standing of the Concept of Political Identity. European Consortium of Political Research (ECPR) : General Conference Papers, Université de Montreal. Montreal, Canada, 2015.

20. Loth W. Identity and Statehood in the process of European Integration. Journal of European Integration History. 2000. № 6. P. 9-26.

21. The dynamics of political identity and issue attitudes in adolescence and early adulthood / R. Rekker et al. Electoral Studies. 2017. DOI: 10.1016/j.electstud. 2017.02.005.

22. Risse T. The Euro between National and European Identity. Journal of European Public Policy. 2003. August. № 10 (4). P. 487-505.

23. Shanks M., Miller W. Policy Direction and Performance Evaluation: Contemporary Explanations of the Reagan Elections. British Journal of Political Science.1990. Vol. 20. № 2. P. 143-235.
24. Strath B. A European Identity: to the historical limits of a concept. European Journal of Social Theory. 2003. № 5. P. 387-401.

25. Van Bavel J.J., Pereira A. The Partisan Brain: An Identity-Based Model of Political Belief. Trends in Cognitive Sciences. 2018. № 22 (3). P. 213-224. DOI: 10.1016/j.tics.2018.01.004.

26. Vignoles V.L. Identity: Personal and Social. The Oxford Handbook of Personality and Social Psychology I edited by Kay Deaux, Mark Snyder. Second Edition. New York: Oxford University Press, 2019.

27. Welsh J.M. The role of the inner enemy in European self-definition: Identity, culture and international relations theory. History of European Ideas. 1994. Vol. 19. Issue 1-3. P. 53-61.

28. Winterich K.P., Zhang Y., Mittal V. How political identity and charity positioning increase donations: Insights from Moral Foundations Theory. Intern. J. of Research in Marketing. 2012. № 29. P. 346-354. 